\title{
‘Abd al-Majīd al-Najjār's Perspective on Maqāṣid al-Sharī’ah
}

\author{
Faishal Agil Al M unawar \\ UIN Maulana Malik Ibrahim Malang \\ e-mail: faishalagilalmunawwar@uin-malang.ac.id
}

\begin{tabular}{|l|l|l|}
\hline Received: 09-07-2021 & Revised: 23-10-2021 & Accepted: 11-11-2021 \\
\hline
\end{tabular}

Abstract: Maqāṣid Al-Sharìah is a discipline that gives enlightenment on understanding and development of Islamic law. Moreover, it can also be used as a verdict (Istinbät) for a Mujtabid. This particular research discusses 'Abd Al-Majīd Al-Najjär and his unique perspective on Maqāșid Al-Sharì' ah. The research encompasses library research category with descriptive qualitative approach to point out and reveal Abdul Majid An-Naijar's Maqäșid Al-Shariah views. The result displays Majority of Maqāșid Al-Sharìah experts (Maqāșidiyyūn), the core of Maqāṣid Al-Sharì'ah is to manifest AlDarüriyyät Al-Khams (five substances), but 'Abd Al-Majid Al-Najjär has different notion which is Maquașid Al-Sharìah 'Alā Dawäir Al-Hayāh Al-Insāniyyah (buman life Maqashid Al-Sharīab) that realizes Al-Darüriyyat Al-Thamain (eight substances) that contains HifZ Al-Din (preserving religion), Hifz Insāniyyah Al-Insān (preserving humanity), Hifz Al-Nafs Al-Insāniyyah (protecting soul), Hifz Al-'Aql (preserving mind), Hifz Al-Nasl (preserving heirs), Hifz Al-Kiyān Al-Ijtimā' ì (preserves social behavior), HifZ Al-Mäl (taking care of property) and HifZ Al-Biah (preserving environment) with noble purposes to gain benefits and salvation for here and hereafter. According to 'Abd Al-Majid Al-Najjär, realizing benefits for mankind by materializing merits and avoiding perilous things here and hereafter are the supreme objective of Islamic Shariah.

Abstrak: Maquașid Al-Sharīah merupakan disiplin ilmu yang memberikan pencerahan bagi pemahaman dan pengembangan hukum Islam. Selain itu, juga dapat digunakan sebagai putusan (Istinbäț) bagi seorang mujtahid. Penelitian ini membahas tentang 'Abd AlMajīd Al-Najjār dan keunikan perspektifnya tentang Maqāṣid Al-Shariah. Penelitian ini termasuk kategori penelitian kepustakaan dengan pendekatan kualitatif deskriptif untuk mengungkap pandangan Maqāșid Al-Shariah Abdul Majid An-Najjar. Hasil penelitian menunjukkan mayoritas ahli Maquașid Al-Sharīah (Maqāṣidiyyūn), inti dari Maqāșid AlSharīah adalah mewujudkan Al-Darüriyyät Al-Khams (lima zat), tetapi 'Abd Al-Majīd AlNajjār memiliki perbedaan paham yang merupakan Maqāṣid Al-Sharīab' Alā Dawäir AlHayāh Al-Insāniyyah (kehidupan manusia Maqashid Al-Sharíab) yang mewujudkan AlDarüriyyät Al-Thamān (delapan zat) yang mengandung Hifz Al-Din (memelihara agama), Hifż Insāniyyah Al-Insān (memelihara kemanusiaan), Hifż Al-Nafs Al-Insāniyyah (memelihara jiwa), Hifz Al'Aql (memelihara akal), Hifz Al-Nasl (memelihara ahli waris), Hifz Al-Kiyān Al-Ijtimä' (memelihara perilaku sosial), Hifz Al-Mäl (menjaga harta) dan HifZ Al-Biah (melestarikan lingkungan) dengan tujuan mulia untuk memperoleh manfaat dan keselamatan dunia dan akhirat. Menurut 'Abd Al-Majīd AlNajjār, mewujudkan manfaat bagi umat manusia dengan mewujudkan pahala dan menghindari hal-hal yang berbahaya di dunia dan di akhirat adalah tujuan tertinggi syariat Islam.

Keywords: Maqāșid Al-Sharīah, Perspective, 'Abd Al-Majūd Al-Najjār, Maqāṣid Al-Sharīah 'Alā Dawāir Al-Hayāh Al-Insāniyyah. 


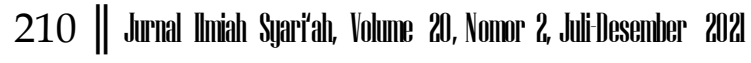

\section{INTRODUCTION}

$\mathcal{T}$ here have been many new issues and important cases to discuss during rapid development of the world. Hence, it needs knowledge that is able to enlighten the understanding and development of Islamic law that is the knowledge of Maquạsid Al-Sharīah.

For those who want to reach mujtahid level, they have to fulfill the first requirement on which they have to understand Maqāṣid Al-Sharī'ah completely and comprehensively. As Abū Isḥāq Al-Shātibī urged (Died in 790H) (AlThūfì, 1987: 46).

The knowledge of a mujtahid towards Maqāșid Al-Sharīah will lead to the understanding of God's provisions and decrees. The mujtahid will also develop Islamic law based on God's will (Al-Khādimī, 1998: 52).

Thus, Maqāșid Al-Sharīah in this era is highly required by a mujtahid in order to be implemented as istinbāt method of Islamic law in solving contemporary matters (Al-Qahṭān, 2010: 328).

Generally, the essence of Maqāsid AlSharīah is Jalb Al-Mașälih Wa Daf' AlMafāsid (gain benefit and avoid all kinds of damage or hazardous things) to gain benefit and salvation for here and hereafter by realizing five primary needs (Al-Darūriyyāt Al-Khams): preserving religion (Hifụ Al-Dīn), protecting soul (Hifz Al-Nafs), preserving minds (Hifz Al'Aql), preserving heirs (Hifz Al-Nasl), and taking care of property (Hifụ Al-Māl) (AlShāțibī, 2004: 222).

All things in the world are created for humans to give benefit, as long as there is no Naș (Al-Qur'an and Hadith texts) which forbid (harām) them, neither the explanations of their dangers. This prevention is to maintain and look after
Al-Darūriyyāt (the primary needs) of society (Jābir, 2011: 5).

Imām Abū Hāmid Al-Ghazālī (Died in $505 \mathrm{H}$ ) in his book Al-Mustașfā wrote: "the intention of Sharīah in making the five primary needs is for people to preserve, protect, and take care of their religion, souls, minds, heirs, and properties, because maintaining those needs is a utility. In other words, ignoring them is a fault. Avoiding any action of omitting those needs is considered as the strongest significance (Aqwa Al-Marātib Fì Al-Mașālih), because the purpose of Sharī'ah is to give benefit to people. As long as it does not against prohibitions such as being infidel (Tahrīm Al-Kufr), murdering (Taḥrīm Al-Qatl), doing adultery (Tahrīm Al-Zinā), stealing (Taḥīm Al-Sariqah), drinking alcoholic beverages or getting drunk (Tahrīm Shurb Al-Muskir) (Al-Ghazālī, 1997: 287-288).

The researcher found that there is a contemporary Islamic scholar from Tunisia that had expertise in the discipline of Maqāṣid Al-Sharī'ah just like Muḥammad Al-Ṭāhir bin 'Āshūr (died in $1973 \mathrm{M}$ ), he is 'Abd Al-Majīd Al-Najjār (born in Bani Kheddache of Tunisia on May 28 ${ }^{\text {th }}$ 1945) who has different viewpoint from the majority of Maqāṣid Al-Sharī'ah experts (Maqāṣidiyyūn) in discussing it based on his book AlSharī'ah Bi Ab'ād Jadīdah. He also has around 28 books. Thus, it is interesting to discuss this notion in this article (AlNajjār, 2008: 294-295).

Most of Maqāșid Al-Sharī'ah experts (Maqāṣidiyyūn) defined the essence of Maqāṣid Al-Sharī'ah as the realization of five primary needs (Al-Darūriyyāt AlKhams) which concerns with preserving religion (Hifž Al-Dīn), protecting soul (Hifz Al-Nafs), preserving minds (Hifz Al'Aql), preserving heirs (Hifu Al-Nasl), and 


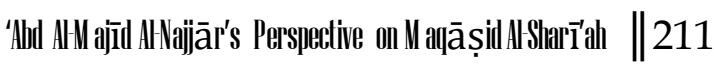

taking care of property (Hifz Al-Māl), meanwhile 'Abd Al-Majīd Al-Najjār determined the essence of Maqāṣid AlShari' ah as the realization of eight primary needs (Al-Darūriyyāt Al-Thamān) and has a new term of it as Maqāṣid Al-Sharī'ah in the area of human's life (Maqāṣid AlSharī'ah 'Alā Dawāir Al-Ḥayāh AlInsāniyyah) which deals with preserving religion (Hifz Al-Dīn), preserving humanity (Hịẓ̨ Insāniyyah Al-Insān), protecting soul (Hifz Al-NafsAlInsāniyyah), preserving minds (Hifz Al'Aql), preserving heirs (Hifz Al-Nasl), preserving society behavior (Hifẓ Al-Kiyān Al-Ijtimā'î), taking care of property (Hifz Al-Māl), and preserving the environment (Hifz Al-Bīah) in order to get the benefit and avoid the damage, thus people can gain salvation here and hereafter.

Even though the researcher did not find any article related to 'Abd Al-Majīd Al-Najjārr's Maqāșid Al-Sharī'ah, but most of the articles which mentioned him discussed Sharíah economics, except one that discussed Islamic law. Hence, it is interesting to discuss.

First, there is an article written by Houssem Eddine Bedoui dan Walid Mansour entitled "Performance and Maqasid al-Shari'ah's Pentagon Shaped Ethical Measurement" which was published by Springer Science + Business Media Dordrecht in 2014.

Second, there is an article written by Wasyith. The title is "Beyond Banking: The Revitalization of Maqāṣid in Sharīah Banking". It was published by Economica: Islamic Economics Journal 2017.

Third, there is an article written by Sayed Sikandar Shah Haneef and Mohd Abbas Bin Abdul Razak entitled "Stabilizing Muslim Marriages: Some Reflections on Ethical Management of Family Law" which was published by
MAZAHIB Islamic Legal Thought Journal in 2017.

Fourth, there is an article written by Siti Amaroh which is "Maqāṣid AlSharīah-based Social Performance Assessment at Converted Sharī'ah Commercial Banks in Indonesia.

Fifth, there is an article written by Marziana Madah Marzuki and Wan Zurina Nik Abdul Majid entitled "Fraud Prevention in Malaysia: Maqasid alShariah Perspective" which was published by Global Business and Management Research: An International Journal in 2020.

This research aimed at revealing and answering the main issue: how is 'Abd AlMajīd Al-Najjār's perspective on Maqāṣid Al-Shari'ah? Thus, researcher discussed 'Abd Al-Majīd Al-Najjār's perspective on Maqāṣid Al-Sharì'ah in order to find out and explain why the essence of 'Abd AlMajīd Al-Najjār's Maqāșid Al-Sharī'ah is different from the essence of most of Maqāṣid Al-Sharī'ah experts (Maqāṣidiyyūn).

\section{RESEARCH METHODS}

This research is a library research because it discusses the document and sources from libraries which are related to 'Abd Al-Majīd Al-Najjār's Maqāṣid AlShari'ah. The approach used in this research was qualitative descriptive which was intended to reveal and explain 'Abd Al-Majīd Al-Najjār's Maqāșid Al-Sharī'ah (Salim and Syahrum, 2012). The result of this research was about 'Abd Al-Majīd AlNajjār's perspective on Maqāṣid AlShari'ah. The intention was to answer and explain 'Abd Al-Majīd Al-Najjār's perspective on Maqāṣid Al-Sharī'ah. 


\section{RESULT AND DISCUSSION}

\section{The Definision of Maqāșid Al-Sharī'ah Based on 'Abd Al-Majīd Al-Najjār}

The definition of Maqāṣid AlSharī'ah stated by 'Abd Al-Majīd AlNajjār is based on the definition proposed by two contemporary scholars of Maqāșid Al-Sharī'ah, they were Muhammad AlTāhir bin 'Âshūr (died in 1973) and 'Allāl Al-Fāsī (died in 1974).

The definition of Maqāṣid AlSharī'ah according to Muhammad AlTāhir bin 'Āshūr:

$$
\text { "مقاصد الشريعة العامة هي المعاني والملكم }
$$

"Generally, Maqāṣid Al-Sharī'ah is the meanings and wisdoms guided by God (Allah Subhanahu wa Ta'ala) in every form of Shari'ah determination or most of them ('Âshūr, 2007: 49).

Meanwhile, according to 'Allāl AlFāsī, Maqāṣid Al-Sharī'ah is:

$$
\text { "المراد .مقاصد الشريعة: الغاية منها، والأسرار }
$$

“The definition of Maqāṣid Al-Sharī'ah is the purpose of Shari'ah and the secrets determined by Al-Shāri' (Allah Subhanahu wa Ta'ala) in every law of its Sharī'ah laws (Al-Fāsī, 1993: 7).

Based on both definitions from those contemporary scholars, 'Abd Al-Majīd AlNajjār defined Maqāṣid Al-Sharī’ah as follow:

$$
\text { "الغاية التي منأجلهاوضعتتلك الشريعةفيكلياها وجزئياةا }
$$

"Every purpose from which its cause is determined by Sharī'ah both kullī (general) dan juzī (specific) where freedom is given to live the life as what has been prescribed and there are kindness and benefits (Al-Najjār, 2008: 16). The meaning of the definition above is the wisdom contained in Shari' ${ }^{\prime}$ ah is the law of Sharī'ah, namely Allah Subhanahu wa Ta'ala created humans to live on Earth as the leader (khalifah) in order to worship Him, to objectify virtue and benefit which is the highest level of purpose of Islamic Sharīah, to achieve blessedness in the world and hereafter.

Thus, the definition of Maqāșid AlSharī'ah according to 'Abd Al-Majīd AlNajjār is "the meanings and wisdoms guided by Al-Shāri' (Allah Subhanahu wa Ta'ala) in every form of Sharī'ah determination or in most of them" and "the purpose of Sharī'ah and the secrets appointed by Al-Shāri' (Allah Subhanahu wa Ta'ala) in each of Sharī'ah laws.

According to Abū Ishāa Al-Shāțibī (died in $790 \mathrm{H}$ ), there are four Al-Shāri's (Allah Subhanahu wa Ta'ala) purposes: 1) Qașdu Al-Shāri' Fī Waḍ'i Al-Sharī'ah, it is the purpose of Al-Shāri' (Allah Subhanahu wa Ta'ala) in determining the Sharī'ah; 2) Qaṣdu Al-Shāri' Fì Waḍ'i AlSharī'ah Li Al-Ifhām, it is the purpose of Al-Shāri' (Allah Subhanahu wa Ta'ala) in determining the Sharī'ah to be understood easier; 3) Qașdu Al-Shāri' Li Al-Taklīf Bi Muqtada Al-Sharī'ah, it is the purpose of Al-Shāri' (Allah Subhanahu wa Ta'ala) in determining the Sharī'ah to be applied based on His commands; and 4) Qașdu Al-Shāri' Fī Dukhūl Al-Mukallaf Taḥta Hukm Al-Sharī'ah, it is the purpose of AlShāri' (Allah Subhanahu wa Ta'ala) in guiding humans to be under the auspices of Sharī'ah law (Al-Shātibīi, 2004: 219). Allah didn't determine Sharī'ah without beneficial purpose for humans. (Al-Najjār, 2008: 18)

According to 'Abd Al-Majīd AlNajjār, there are four ways (masālik) to 
find out Maqāșid Al-Sharī'ah: 1) Maslak Al-Amr Al-Ilāhī, it is the understanding of Sharīah which is related to God's commands and guidance both obeying the rules and avoiding sins; 2) Maslak AlBayān Al-Nașșī, it is the understanding of Nas (the written form of Al-Qur'an and Hadìth) both qat 'i $i$ and zannī or explicit and implicit meanings; 3) Maslak Al-Istiqrā', it is the understanding of Al-Istiqrä ${ }^{\prime}$ (inductive) method from Kulli (general) to $J u z \bar{\imath}$ (specific); 4) Maslak Al-'Amal AlNabawi $\overline{1}$, it is the understanding of the practice done by Rasulullah Muhammad Sallallahu Alayhi wa Salaam. (Al-Najjār, 2008: 25-35)

According to Wahbah Al-Zuhaylī (Died in 2015) something can be said as Maqāṣid Al-Sharī'ah if it meets four requirements: 1) Thābit, it means consistent and doubtless; 2) Zāhir, it is clear and no contradiction of 'illah (the reason of Sharī'ah purpose; 3) Mundabit, it is measureable and has clear standard limits (jāmi' māni'); 4) Munțarid, it is generally applied. (Al-Zuhaylī, 1986: Jilid 2, 1018)

Meanwhile, Nūr Al-Dīn bin Mukhtār Al-Khādimī states that something can be said as Maqāṣid Al-Sharī'ah if it meets four main requirements: "1) it must have purposes and secrets; 2) the purposes and secrets are part of Sharī'ah law; 3) the purposes and secrets must be based on obedience to God ('ubūdiyyah); 4) the purposes and secrets to be achieved must be beneficial both for here and hereafter". (Al-Khādimī, 1998: 52)

Therefore, the wisdom that meets requirement can be called Maqāṣid AlSharī'ah, meanwhile everything which is merely based on unconscious possibility (wahm) or imagination is definitely not Maqāṣid Al-Sharī’ah.
Thus, Maqāṣid Al-Sharī'ah can be one of istinbāt methods of Islamic law (the method of determining Islamic law), because the knowledge towards Maqāșid Al-Sharī'ah will lead mujtahid to comprehend God's provisions and decrees, and develop Islamic law based on God's will (Al-Khādimī, 1998: 52).

As stated by Nūr Al-Dīn bin Mukhtār Al-Khādimī, there are many Naș (the written form of Al-Qur'an and Hadīth) that discuss Maqāṣid Al-Sharī'ah, but it is quite difficult to sort them, but some of the scholars use certain Nas as the basic law of Maqashid Asy-Syari'ah (AlKhādimī, 2001: 78).

Several Nas that become the basic law for Maqāṣid Al-Sharī'ah are:

1) Al-Quran, there are 7 verses: The Quran 2: 185 (Al-Baqarah), The Quran 4: 28 (AnNisa'), The Quran 5: 6 (Al-Maidah), The Quran 7: 157 (Al-A'raf), The Quran 22: 78 (Al-Hajj), The Quran 65: 7 (Ath-Thalaq).

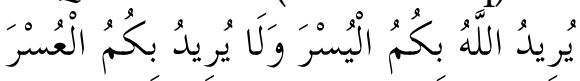

"Allah desires for you ease and $\mathrm{He}$ does not desire for you difficulty" (The Quran 2: 185, Al-Baqarah).

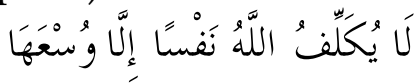

"Allah does not obligate anyone beyond his capacity" (The Quran 2: 286, Al-Baqarah).

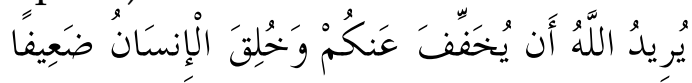

"Allah wants to lighten for your difficulties, and mankind was created weak" (The Quran 4: 28, An-Nisa).

$$
\text { مَا يُريدُ اللَّهُ لِيَجْعَلَ عَلَهِكُمُ }
$$

"Allah does not want to lay any hardship upon you" (The Quran 5: 6, AlMaidah).

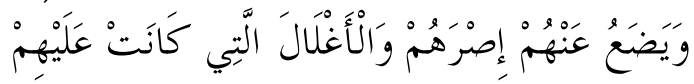


"And relieves them of theirs burden, and of the shackles that were upon them" (The Quran 7: 157, Al-A'raf).

$$
\text { وَمَا جَعَلَ عَلَنْكُمْ فِي الدِّينِ مِنْ حَرَجِ }
$$

"And He has not laid upon you any hardship in the religion" (The Quran 22: 78, Al-Hajj);

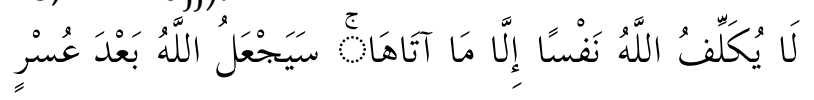

$$
\begin{aligned}
& \text { يُسنرًا }
\end{aligned}
$$

"Allah does not charge a soul except what he has given it. Allah will bring about, after hardship, ease" (The Quran 65:7, Ath-Thalaq).

2) The Prophet's Hadith. There are 3 Hadīths:

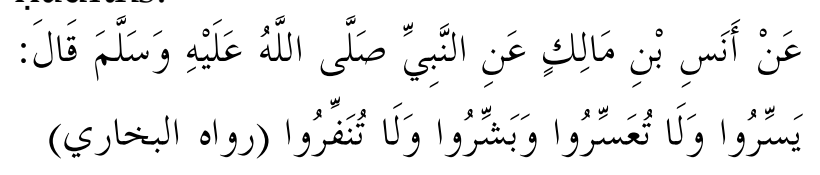

Narated by Anas bin Malik, The Prophet said "Make things easy for the people, and do not make it difficult for them, and make them calm with glad tidings, and do not repulse them" $\{\mathrm{Al}$ Bukhari Hadīth, (Al-Bukhari, 2002: 30)\}.

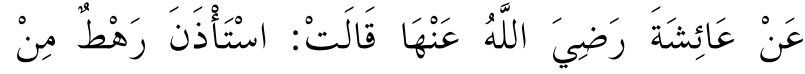

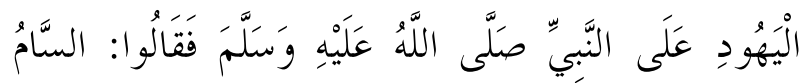

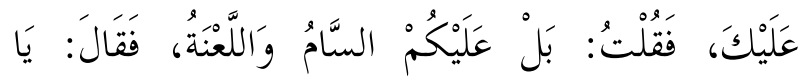

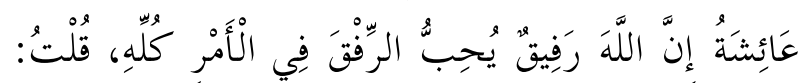

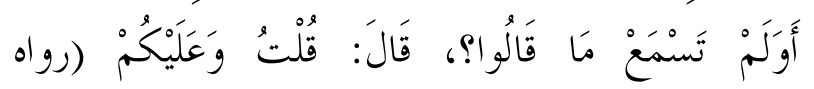

$$
\text { (البخاري) }
$$

'Aisha said that the Jews came to the Prophet and said, "As-Samu 'Alaikum" (death be on you). "Aisha said to them, "Death be on you, and may Allah curse you and shower His wrath upon you!" The Prophet said, "Be calm, O 'Aisha! You should be kind and lenient, and beware of harshness and bad words." She said to the
Prophet "haven't you heard what they have said?" The Prophet said "I said: wa'alaikum (even for you)" \{Al-Bukhari (Al-Bukhari 2002: 1713)\}.

$$
\begin{aligned}
& \text { عَنْ عَائِشَةَ رَضِيَ اللَّهُ عَنْهَا قَالَتْ: اسْتَأْذَنَ رَهْطُ مِنْ }
\end{aligned}
$$

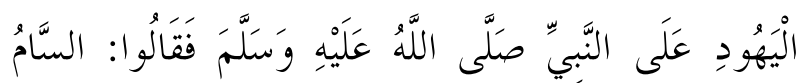

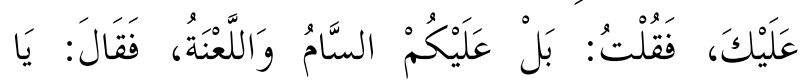

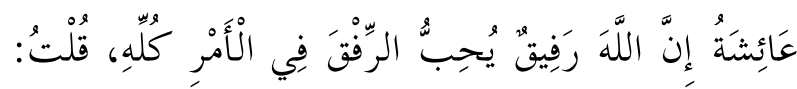

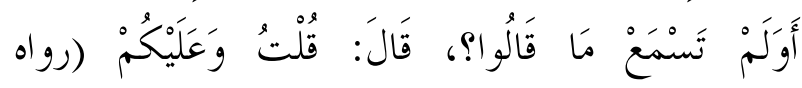

$$
\begin{aligned}
& \text { (البخاري) }
\end{aligned}
$$

Narrated by Abu Hurairah, he said: "Rasulullah SAW said: "Indeed, this religion is easy, and no one will ever overburden himself in religion, except that it will overcome him. So, seek what is appropriate, and come as close as you can, and receive the glad tidings (that you will be rewarded), and takeit easy; and gain strength by worshipping in the mornings, afternoons, and during the last hours of the nights." (Al-Nasā'̄í, 2010: 1713)\}.

Therefore, Maqāṣid Al-Sharī'ah that aims at getting benefit has strong foundation in its discovering and developing.

The theorem to create the basic law of Maqāṣid Al-Sharī'ah definitely does not lay on some verses and hadith only, but when other certain verses and Hadith are studied and result in benefit, moreover it has the same result with other studies of verses and Hadith, then it can be concluded inductively (Istiqrā') that all Sharī'ah laws aim at giving benefit.

Hence, to continue it, the scholars have to do their best in determining Islamic law in order to achieve the kindness that God wants for humans.

The existence of Maqāṣid Al-Sharī'ah as legal theory that eventually becomes an independent scientific discipline is 


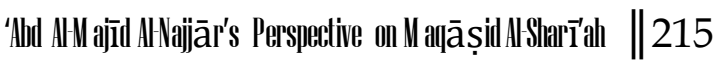

actually from the agreement of the majority of scholars and mujtahid (Ijma').

From Ijma' perspective, salaf and khalaf scholars have agreed that Islamic Sharīah contains easiness and removes burden (taklif) which cannot be carried by people (Nūr Al-Dīn bin Mukhtār AlKhādimìi, 2001: 11).

\section{'Abd Al-Majīd Al-Najjār's General Perspective on Maqāṣid Al-Sharī'ah}

'Abd Al-Majīd Al-Najjār classified Maqāșid Al-Sharīah generally into five aspect just like what the majority of the experts (Maqāșidiyyūn) did towards it (Al-Najjār, 2008: 38-49). Those aspects are:

1. Al-Maqāṣid Bihasabi Quwwah AlThubūt, it is Maqāṣid Al-Sharī'ah from the aspect of legal force which is divided into three categories:

a. Al-Maqāșid Al-Qațiyyah, it is the absolute (qaț'i) and successive (mutawātir) Maqāṣid Al-Sharī'ah stated in Nas (the written forms of Al-Quran or Hadith) with the result that it becomes doubtless knowledge (fi al-din al-yaqin) and is required by Sharī'ah such as the purpose of qișās law to get rid of the threat for the sustainability of human life \{Hifz alhayāāh (Al-Najjār, 2008: 38)\}.

b. Al-Maqāṣid Al-Zanniyyah, it is the Maqāṣid Al-Sharīah which is written in Naș, but does not reach the level of mutawatir and can be studied only by zanni way through finding 'illah (the reason of Shari'ah law) or 'istiqra' (inductively), such as the disallowance of ihtikār and kanz al-amwāl (hoard and monopolize property), especially for primary needs, that is the reason beyond the law of buying and selling and ease the agreement and order to give some of the property (Al-Najjār, 2008: 38-39).

c. Al-Maqāṣid Al-Wahmiyyah, it is Maqāṣid Al-Sharī'ah that prioritizes the use of mind and its clear clause cannot be found in Naș. It can even contradict the will in Nas and it can be determined through the principle of simplicity (al-taysīr) which crosses the line. Thus, the danger (mudharat) of it is more than its value (al-naf'), such as getting the benefit of alcoholic beverages to warm body (Al-Najjār, 2008: 40).

2. Al-Maqāṣid Bihasabi Al-Manāt, it is the Maqāṣid Al-Sharī'ah as the object which is divided into 3 categories as well:

a. Al-Maqāṣid Al-Kulliyyah, it is the Maqāṣid Al-Sharī'ah that covers all micro-scaled matters. It needs maximum and sustainable efforts to realize and implement it from the micro to macro scales, such as the principles of al-taysīr (easiness) and raf'u al-haraj (removing difficulty) (Al-Fāsī, 1993: 45-46).

b. Al-MaqāṣidAl-Nau'iyyah, it is Maqāṣid Al-Sharī'ah that has several provisions of Sharīah law only for achieving one purpose only, such as Sharīah law for family rule, for example to strengthen and maintain kinship (Al-Najjār, 2008: 41-42).

c. Al-Maqāṣid Al-Juziyyah, it is Maqāṣid Al-Sharī'ah that its purpose can only be realized through specific determined law, such as wudhu, it is for purifying (Al-Najjār, 2008: 41-42).

3. Al-Maqāṣid Bihasabi Al-Shumūl, it is Maqāṣid Al-Sharīah based on scope and it is divided into two categories:

a. Al-Maqāṣid $\mathrm{Al}$ ' $^{-} \mathrm{A} m m a h$, it is Maqāṣid Al-Sharī'ah that has general purpose. It can be determined 


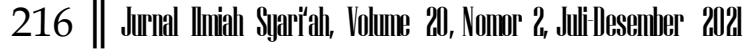

through Islamic law itself by adding and setting new law on darüriyyah level (primary needs) and haajiyyah (secondary needs) such as justice (Al'Adālah) and freedom (Al-Hurriyyah). (Auda, 2008: 6-7; Auda, 2007: 5).

b. Al-Maqāṣid Al-Khāṣṣah, it is Maqāṣid Al-Sharī'ah that has specific purpose and is determined through certain discussion in Islamic law, such as children welfare in the area of family law, taking preventive action in criminal jurisdiction (jinayah), taking preventive action in transaction law when there is monopoly towards individual or certain group (Auda, 2011: 197).

4. Al-Maqāṣid Bihasabi Al-Aṣliyyah, it is Maqāṣid Al-Sharī'ah based on its source. It is divided into two categories:

a. Maqāṣid Al-Ușūl, this Maqāṣid AlSharíah has basic purpose that will be achieved by Islamic law provision itself, such as five primary needs (AlDarūriyyāt Al-Khams): preserving religion (Hifụ Al-Dīn), protecting soul (Hifz Al-Nafs), preserving minds (Hifz Al-'Aql), preserving heirs (Hifz Al-Nasl), and taking care of property (Hifẓ Al-Māl), and also basic principles that are automatically parts of the Islamic law itself such as the principle of justice (al-'adālah), the principle of freedom (al-hurriyyah), the principle of human equality (al-musawāh), the principle of wisdom (al-hikmah), and the principle of kindness for humanity (mașāliḥ al-'ibād).

b. Maqāṣid Al-Wasāil, it is Maqāṣid AlShari'ah that is a medium to achieve Maqāṣid Al-Ușūl (basic purpose), thus, it has to go through Maqāṣid Al-Wasāil or Al-Maqāṣid Al-Tābi'ah (certain medium) (Al-Najjār, 2008: 45-46).

5. Al-Maqāṣid Bihasabi Quwwah AlMașlahaḥ, it is Maqāṣid Al-Sharī'ah from the angle of Mașlahah capacity which is divided into 3 categories:

a. Al-Maqāṣid Al-Ḍarūriyyāh, it is Maqāṣid Al-Sharī'ah that shows the level of need that must be fulfilled (primary need), if it is not fulfilled, then it will threaten human safety both in the world and hereafter (Lihasasanah, 2008: 19), such as five primary needs (Al-Ḍarūriyyāt AlKhams): preserving religion (Hifz Al-Dīn), protecting soul (Hifz AlNafs), preserving minds (Hifz Al'Aql), preserving heirs (Hifz AlNasl), and taking care of property (Hiifu Al-Māl), ('Awdah, t.th: 203). And also like qiṣās law to get rid of the threat for human's life (Al-Najjār, 2008: 47-48).

b. Al-Maqāṣid Al-Ḥājiyyah, it is Maqāṣid Al-Sharī'ah that shows the level of secondary needs. If this level cannot be fulfilled, then it will not bring any harm to human's life, but it can bring difficulty (mashaqqah), because removing all burdens are the basic spirit of Islamic Sharī'ah, such as rukhșah (relief) for wayfarer or traveler for not fasting in Ramadan and pay it back in another day (AlShāțibī, 2004: 222).

c. Al-Maqāṣid Al-Tahsīniyyah, it is Maqāṣid Al-Sharī'ah that shows the level of tertiary needs. This need will not bring any harm to the sustainability of any of five primary needs (Al-Ḍarūriyyāt Al-Khams) on the level of Darūriyyāh (primary needs) and it will not bring any difficulty (mashaqqah) as well on hājiyyah (secondary needs). Thus, 
this need is only for complement and to beautify which is related to general behavior in the area of mu'amalah, such as suggestion for dressing up before going to a mosque (Al-Ghazālī, 1997: 217).

Thus, general classification of Maqāṣid Al-Sharī'ah based on 'Abd AlMajīd Al-Najjār is similar to the one of the majority of the experts by which it is divided into 5 aspects:

1) Al-Maqāṣid Bihasabi Quwwah AlThubūt;

a) Al-Maqāṣid Al-Qaț'iyyah.

b) Al-Maqāṣid Al-Ẓanniyyah.

2) Al-Maqāṣid Bihasabi Al-Manāț;
a) Al-Maqāṣid Al-Kulliyyah
b) Al-MaqāṣidAl-Nau'iyyah.
c) Al-Maqāṣid Al-Juziyyah.

3) Al-Maqāṣid Bihasabi Al-Shumūl;
a) Al-Maqāṣid Al-'Āmmah.
b) Al-Maqāṣid Al-Khāṣṣah.

4) Al-Maqāṣid Bihasabi Al-Aṣliyyah;
a) Maqāṣid Al-Ușūl.
b) Maqāṣid Al-Wasāil.

5) Al-Maqāṣid Bihasabi Quwwah AlMașlahah;
a) Al-MaqāṣidAl-Darūriyyāh.
b) Al-Maqāṣid Al-Ḥājiyyah.
c) Al-MaqāṣidAl-Taḥsīniyyah.

\section{Figure of General Classification of Maqāṣid Al-Sharī'ah}

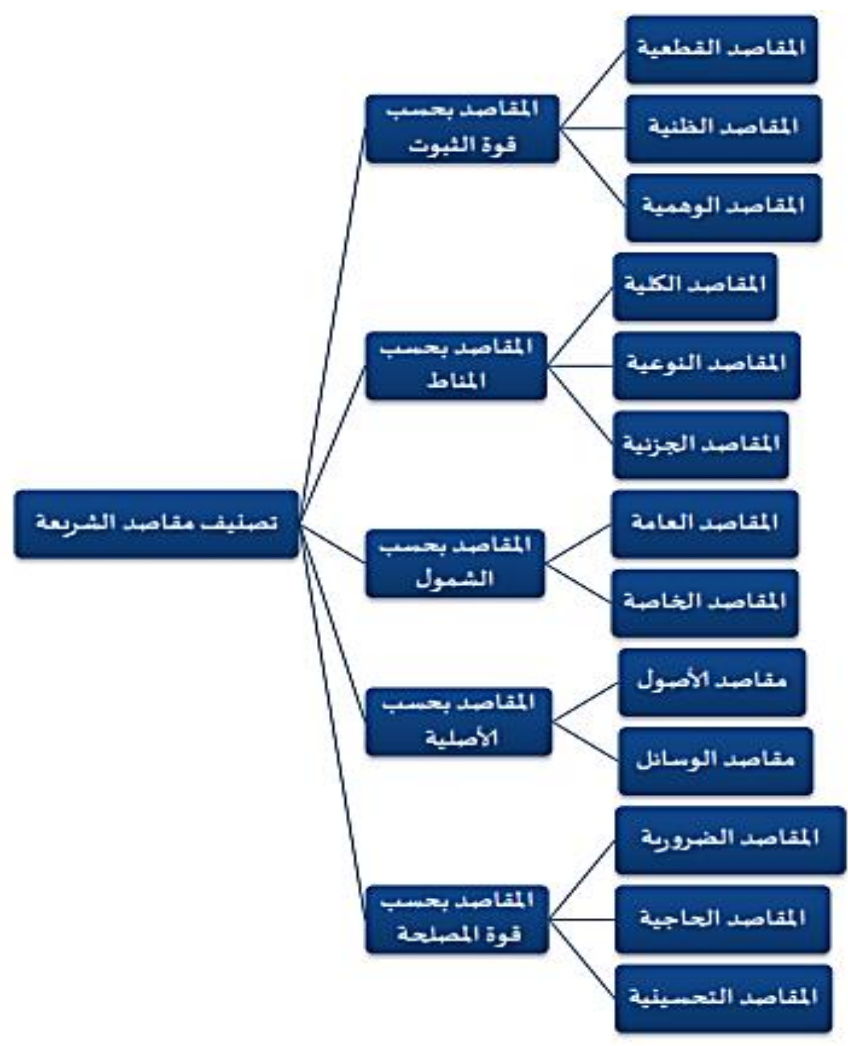

\section{'Abd Al-Majīd Al-Najjār's Specific Perspective on Maqāṣid Al-Sharī'ah}

'Abd Al-Majīd Al-Najjār classified Maqāṣid Al-Sharī'ah specifically by using new term, Maqāṣid Al-Sharī'ah 'Alā Dawāir Al-Ḥayāh Al-Insāniyyah. It is Maqāṣid Al-Sharī'ah in human's life that is divided into 4 aspects (Al-Najjār, 2008: 59-236):

1. Al-Maqāṣid Fī Hịẓ Qimah Al-Hayah Al-Insaniyyah. This Maqāṣid AlSharīah is in the area of maintaining the value of human's life in which it maintains two main aspects such as Hifź Al-Dīn (preserving religion) and HifẓInsāniyyah Al-Insān (preserving humanity) (Al-Najjār, 2008: 59-83). The purposes of those main aspects are:

a. Maqșad Hifẓ Al-Dīn (preserving religion). This aspect is divided into two points:

1) Ḥifẓ Al-Dīn Bi Tawfīr Asbābihi, it is about preserving religion with 
certain reasons. It is divided into 4 categories:

a) Hifz Al-Dīn Bi Al-Taysīr, it is about preserving religion by make it easy, because religion is simple.

b) Hifẓ Al-Dīn Bi Al-ljtihād, it is preserving religion by doing ijtihad for the religion.

c) Hifz Al-Dìn Bi Al-Tablīgh, it is preserving religion by conveying it or doing $d a^{\prime} w a h$.

d) Ḥifz Al-Dīn Bi Al-Sulțān, it is preserving religion by using authority power.

2) Ḥifz Al-Dīn Bi Daf' Al-'Awātiq, it is preserving religion by avoiding the practice of slavery for religion. It is divided into 5 categories:

a) Hifẓ Al-Dīn Bi Mudāfa'ah AlHawāya, it is preserving religion by avoiding the use of carnality in all aspects of religion.

b) Hiifz Al-Dīn Bi Mudāfa'ah AlIstibdād Al-Fikrī, it is preserving religion by avoiding the use of dictatorial thoughts or oppressing action in all aspects of religion.

c) Hifž Al-Dīn Bi Mudāfa'ah AlTahrîf, it is preserving religion by avoiding digression in all aspects of religion.

d) Hifž Al-Dīn Bi Mudāfa'ah AlIrjāf, it is preserving religion by avoiding fear in all aspects of religion.

e) Ḥifž Al-Dīn Bi Al-Jihād, it is preserving religion by doing jihad.

b. Maqșad Hifẓ Insāniyyah Al-Insān, the purpose of this is to preserving humanity and it is divided into four points:
1) Hifz Al-Fițrah Al-Insāniyyah, it is about preserving humanity by maintaining human nature. It is divided into 3 categories:

a) Hifz Al-Fițrah Min Al-Tabdīl, it is about maintaining human nature by avoiding inappropriate changes.

b) Ḥifẓ Al-Fițrah Bi Al-Tawāzun, it is about maintaining human nature by promoting calm and balance.

c) Hifz Al-Fițrah Bi Al-Ishbā', it is about maintaining human nature by perfecting and accomplishing the flaw of human nature.

2) Ḥifz Al-Karāmah Al-Insāniyyah, it is about maintaining human glory because human is the most perfect creature.

3) Hịẓ Ghāiyah Al-Ḥayāh, it is about maintaining the purposes of life

4) Hifẓ Al-Hurriyyah Al-Insāniyyah, it is about preserving humanity by giving freedom right for people.

2. Al-Maqāṣid Fì Hifẓ Al-Dhāt AlInsāniyyah, it is Maqāṣid Al-Sharī'ah in maintaining the essence of human which is divided into two main aspects: Hifẓ Al-Nafs Al-Insāniyyah (protecting the soul) and Hifz Al-'Aql (preserving minds) (Al-Najjār, 2008: 84-110). The purposes of those aspects are:

a. Maqșad Hifẓ Al-Nafs Al-Insāniyyah, It is about protecting the soul. It is divided into two points:

1) Al-Hifž Al-Mādī Li Al-Nafs, it is about protecting the soul by providing material aspect for soul. And it is divided into two categories as well:

a) Hiifẓ Al-Nafs Bi Asbāb Al-Baqā Wa Al-Quwwah, it is about protecting the soul by keeping 


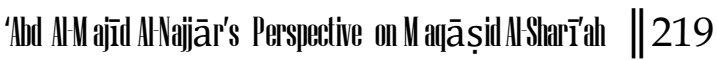

determination and strength for it.

b) Ḥifẓ Al-Nafs Bi Daf' Al-'Awādī, it is about protecting the soul by avoiding inequity for it.

2) Al-Hifz Al-Ma'nawī Li Al-Nafs, it is about protecting the soul by providing non material aspect or moral for it. it is also divided into two:

a) Hifz Al-Nafs Bi Al-Tazkiyah, it is about protecting the soul by keeping it with purification of the soul.

b) Hifz Al-Nafs Bi Al-Amn AnNafsī, it is about protecting the soul by providing safety and security for it.

b. Maqșad Hifz Al-'Aql, this is the purpose of preserving minds which is divided into two aspects:

1) Al-Hifẓ Al-MādīLi Al-'Aql, it is about preserving minds by providing material aspect for it.

2) Al-Hịz Al-Ma'nawī Li Al-'Aql, it is about preserving minds by providing non material aspect or moral for it. it is divided into two categories:

a) Hifz Al-'Aql Bi Taḥrīr Al-Fikr, it is about preserving minds by giving freedom of thought.

b) Hifz Al-'Aql Bi Al-Ta'allum, it is preserving minds by studying. It is divided into 3 categories:

A. Hifz Al-'Aql Bi Al-Ta'allum Al-Istī'ābī, it is about preserving minds by studying deeply.

B. Hifz Al-'Aql Bi Al-Ta'allum Al-Tafakkurī, it is about preserving minds by learning how to think.

C. Hifz Al-'Aql Bi Al-Ta'allum Al-Manhajī, it is about preserving minds by studying methodologically.

3. Al-Maqāṣid F̄̄ Hịẓ Al-Mujtama', Maqāșid Al-Sharī'ah in preserving society which keeps two main points: HifżAl-Nasl (preserving the heirs) and Ḥifz Al-Kiyān Al-Ijtimā'ī (preserving society behavior) ('Abd Al-Majīd AlNajjār, 2008: 111-142). The purposes of those points are:

a. Maqșad Hifz Al-Nasl, the purposes of preserving the heirs are:

1) Hifz Al-Nasl Bi Al-Injāb, it is about preserving the heirs by giving births.

2) Hifz Al-Nasl Bi Hifz Al-Nasab, it is about preserving the heirs by keeping the lineage.

b. Maqșad Hiifu Al-Kiyān Al-Ijtimā'î̀, the purpose of this is to keep the existence and society behavior which is divided into two points:

1) Hifz Al-Muassasah AlIjtimā'iyyah, it is done by maintaining social foundation. This way is divided into 3 categories:

a) Al-Ḥifẓ Bi Thaqāfah AlMuassasah, it is done by maintaining the culture of social foundation.

b) Al-Hifz Bi Muassasah Al-Usrah, it is done by establishing family social foundation.

c) Al-Hifẓ Bi Muassasah AlDaulah, it is done by establishing state social foundation. Al-Hifz $\quad \mathrm{Bi}$ Muassasah Al-Daulah is divided into two categories:

A. Al-Mujtama' Quwa Mașdar Al-Sulthah, it means society is the source of strength and power for the government. 
B. Al-ShūrāĀliyah Al-Daulah, it means forum is the strength and power for the country

2) Hifź Al-'Alāqāt Al-Ijtimā'iyyah, it means preserving the heirs by maintaining the relations in society. It is divided into 3 categories:

a) Al-Hifz $\mathrm{Bi}$ Rābițah AlUkhuwwah, it is done by forging the bond of brotherhood.

b) Al-Ḥifẓ Bi Mīzān Al-'Adl, it is done by realizing justice in every aspect of society.

c) Al-Hifz Bi 'Alāqah Al-Takāful, it is done by maintaining the loyalty and mutual guarantee.

4. Al-Maqāṣid Fī Hifż Al-Muhịị Al-Mādī, it is Maqāṣid Al-Sharī'ah in maintaining material scope which saves two main points: Hifz Al-Māl (taking care properties) and Hifz Al-Bīah (preserving the environment) (AlNajjār, 2008: 183-236). The purposes of those main points are:

a. Maqșad Hifu Al-Māl, it is the purpose of taking care of properties which is divided into 5 ways:

1) Hifẓ Al-Māl Bi Al-Kasab Wa AlTanmiyah, it is done by investing the properties in order to get profit and also to develop them.

2) Hifž Al-Māl Min Al-Talaf, it is done by avoiding damage. This way is divided into 3 categories:

a) Hifz Al-Māl Min Al-Talaf Al'Abathī, it is about taking care of properties by avoiding useless damage.

b) Hịz Al-Māl Min Al-Talaf AlMufsid, it is about taking care of properties by avoiding destructive damage. c) Hiif̣̂Al-Māl Min Al-Talaf AlSarafī, it is about taking care of properties by avoiding excessive damage.

3) Hifz Al-Māl Bi Ḥimāyah AlMilkiyyah, it is done by maintaining ownership of immovable properties.

4) Ḥifẓ Al-Māl Bi Ḥimāyah Qīmatihi, it is done by maintaining properties' selling value.

5) Hiifz Al-Māl Bi Al-Tadāwul Wa AlTarwijj, it is done by maintaining their rotation and promoting them to get profit.

b. Maqșad Hifz Al-Bīah, it is about preserving the environment. It is divided into 4 ways:

1) Hifž Al-Bīah Min Al-Talaf, it is done by avoiding damage.

2) Hifz Al-Bīah Min Al-Talawwuth, it is done by preventing pollution.

3) Hifz Al-Bīah Min Farț Al-Istihlāk, it is done by avoiding the excessive usage.

4) Hifz Al-BīahBi Al-Tanmiyah, it is done by developing, building, growing, and investing it.

Thus, the specific classification of Maqāṣid Al-Sharī'ah according to 'Abd Al-Majīd Al-Najjār is called by using new term: Maqāșid Al-Sharī'ah 'Alā Dawāir Al-Hayāh Al-Insāniyyah from which it is divided into 4 aspects:

1) Al-Maqāṣid Fī Hifẓ Qimah Al-Hayah Al-Insaniyyah;

a) Hiifẓ Al-Dīn.

b) Ḥifz Insāniyyah Al-Insān.

2) Al-Maqāṣid Fī Hịẓ Al-Dhāt AlInsāniyyah;

a) Hifẓ Al-Nafs Al-Insāniyyah.

b) Hifz Al-'Aql.

3) Al-Maqāṣid Fī Hịf̣ Al-Mujtama';

a) Hiff Al-Nasl.

b) Hiifẓ Al-Kiyān Al-Ijtimā’̄î. 


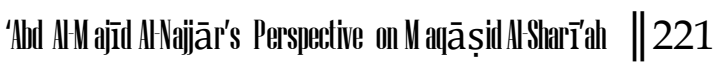

4) Al-Maqāṣid Fī Ḥifẓ Al-Muhịṭ Al-Mādī;

a) Hifẓ Al-Māl.

b) Hịụ Al-Bīah.

\section{Figure of Specific Classification of Maqāṣid Al-Sharī'ah}

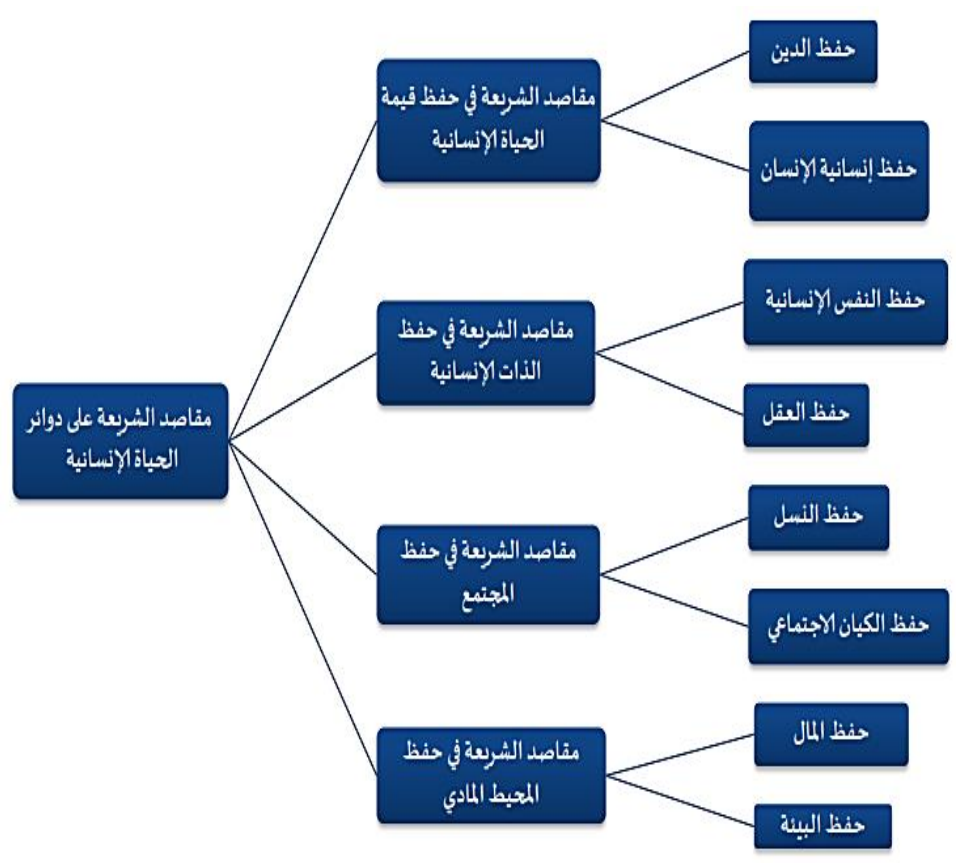

The Result of Analysist Towards 'Abd Al-Majīd Al-Najjār's Perspective on Maqāṣid Al-Sharī'ah

Based on the explanation of 'Abd AlMajīd Al-Najjār's perspective on Maqāșid Al-Sharī'ah both generally and specifically, the author conducted an analysis and got a result as follow: that the essence of Maqāșid Al-Sharī'ah by Abdul Majid An-Najjar is different from the one that has already been agreed by the majority of Maqāșid Al-Sharī'ah's experts (Maqāṣidiyyūn).

The essence of Maqāṣid Al-Sharī'ah according to 'Abd Al-Majīd Al-Najjār is called by using new term, Maqāṣid AlSharī'ah 'Alā Dawāir Al-Ḥayāh AlInsāniyyah (Maqāṣid Al-Sharī'ah in the area of human life), it is implemented to gain benefit and avoid damage in order to get salvation here and hereafter. It is done by actualizing Al-Ḍarūriyyāt Al-Thamān (eight primary needs): preserving religion (Hifẓ Al-Dīn), preserving humanity (Hifz Insāniyyah Al-Insān), protecting soul (Hifẓ Al-Nafs Al-Insāniyyah), preserving minds (Hifz Al-'Aql), preserving heirs (Hifz AlNasl), preserving society behavior (Hifz Al-Kiyān Al-Ijtimā'ì), taking care of property (Hifụ Al-Māl), and preserving the environment (Hifụ Al-Bīah).

'Abd Al-Majīd Al-Najjār determined Maqāṣid Al-Sharī'ah 'Alā Dawāir AlHayāh Al-Insāniyyah (Maqāṣid AlSharī'ah in the area of human life) because the highest purpose of Islamic Sharī'ah is to get benefit and avoid perilous things here and hereafter (Al-Maqșad Al-A'lā Min Al-Sharī'ah Al-Islāmiyyah Huwa AlTaḥqīq Maṣlaḥah Al-Insān Bi Jalb Al-Naf' Lahu Wa Daf' Al-Ḍar 'Anhu FīHayātihi Al-Dunyā Wa FīHayātihi Al-Ukhrā) and Islamic Sharī'ah pay a lot of attention to the detail of human's life comprehensively (Iḥtimāman Shāmilan) (Al-Najjār, 2014: 12).

Hence, Islamic Sharī'ah is designed based on interest of mankind (Mașālih Al'Ibād) and humanitarian purposes (Mașlahah) from various dimensions to balance human's life individually and socially, thus Maqāṣid Al-Sharī'ah covers all macro and micro dimensions individual and social lives (Amaroh, 2018: 18-19).

Meanwhile, the essence of Maqāṣid Al-Sharī'ah based on the majority of its experts (Maqāșidiyyūn) is getting benefit and avoiding damage or danger here and hereafter by actualizing Al-Darūriyyāt AlKhams (five primary needs): preserving religion (Hifz Al-Dīn), protecting soul (Hifz Al-Nafs), preserving minds (Hifz Al'Aql), preserving heirs (Hifu Al-Nasl), and taking care of property (Hif̣ Al-Māl). 
According to the majority of Maqāṣid Al-Sharī'ah experts (Maqāṣidiyyūn) including Abū Hāmid AlGhazālī (Died in 505H), Ibnu Al-Qayyim Al-Jauziyyah (Died in $751 \mathrm{H}$ ), dan Abū Isḥāq Al-Shāțibī (Died in $790 \mathrm{H}$ ), everything written in Al-Quran and AlSunnah becomes the theorem of mașlahah, because Maqāṣid Al-Sharī'ah is oriented to the benefit for humankind, and that benefit as the substance of Maqāṣid AlShari'ah can be realized if the five primary needs (Al-Darūriyyāt Al-Khams) can be actualized (Wasyith, 2017: 6).

\section{Figure of Maqāṣid Al-Sharī'ah According to 'Abd Al-Majīd Al-Najjār}

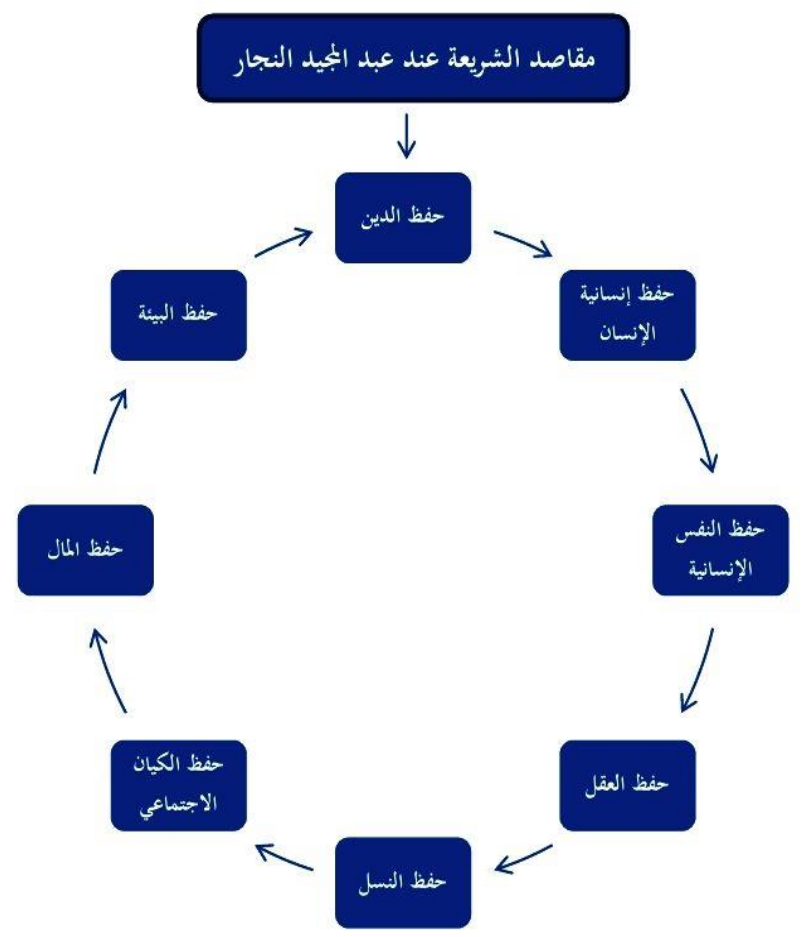

Figure of Maqāṣid Al-Sharīah According to Maqāṣidiyyūn

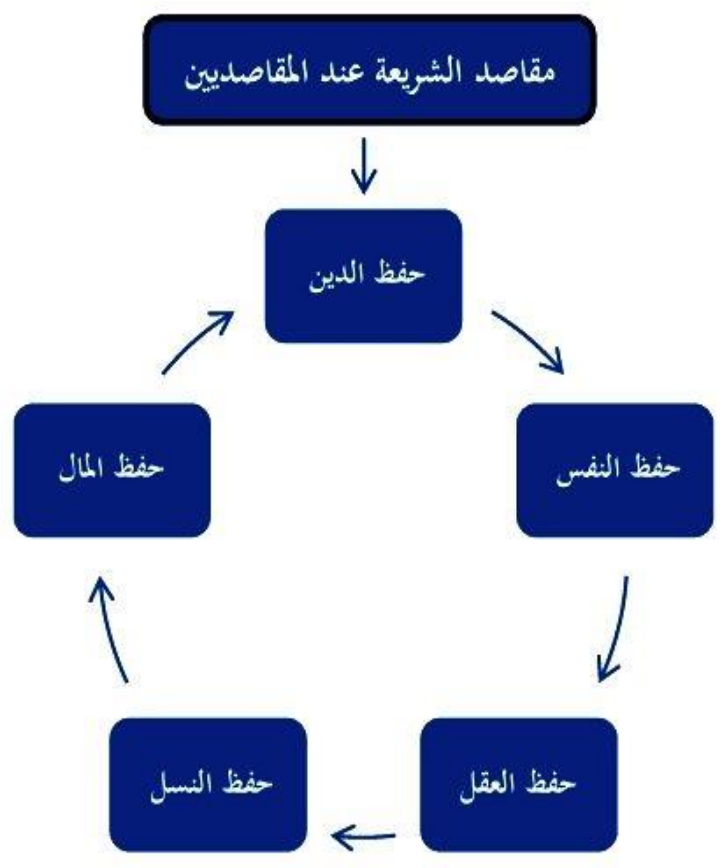

\section{CONCLUSION}

The essence of Maqāșid Al-Sharīah according to 'Abd Al-Majīd Al-Najjār is different from the one agreed by the majority of Maqāșid Al-Sharīah experts (Maqāṣidiyyūn).

According to the majority of Maqāṣid Al-Sharī'ah experts (Maqāṣidiyyūn), the essence of it is the realization of Al-Ḍarūriyyāt Al-Khams (five primary needs), they are preserving religion (Hifz Al-Dīn), protecting soul (Hifz Al-Nafs), preserving minds (Hifz Al'Aql), preserving heirs (Hifz Al-Nasl), and taking care of property (Hifz Al-Māl), meanwhile according to 'Abd Al-Majīd Al-Najjār, the essence of Maqāṣid AlSharī'ah which is called Maqāșid AlSharī'ah 'Alā Dawāir Al-Ḥayāh AlInsāniyyah (Maqāṣid Al-Sharī'ah in the area of human life) is the realization of AlḌarūriyyāt Al-Thamān (eight primary needs) they are preserving religion (Hifz Al-Dīn), preserving humanity (Hifz Insāniyyah Al-Insān), protecting soul (Ḥifẓ Al-NafsAl-Insāniyyah), preserving minds 
(Hifz Al-'Aql), preserving heirs (Hifz AlNasl), preserving society behavior (Hifz Al-Kiyān Al-Ijtimā'ì), taking care of property (Hifẓ Al-Māl), and preserving the environment (Hifž Al-Bīah) in order to gain benefit and avoid damage or perilous things here and hereafter.

According to 'Abd Al-Majīd AlNajjār, the highest purpose of Islamic Sharīah is to gain benefit and avoiding everything that brings harm to people's lives in the world and hereafter, because Islamic Sharī'ah pays a lot of attention to the detail of people's lives comprehensively.

\section{BIBLIOGRAPHY}

Amaroh, S. (2018). PENILAIAN KINERJA SOSIAL BERBASIS MAQASID SYARIAH PADA BANK UMUM SYARIAH HASIL KONVERSI DI INDONESIA. MALIA: Journal of Islamic Banking and Finance, 2(1): 1730.

Al-Bukhārī. (2002). ȘahīhAl-Bukhārī. Beirut: Dār Ibn Al-Kathīr.

Al-Fāsī, 'Allāl. (1993). Maqāṣid Al-Sharī'ah Al-Islāmiyyah Wa Makārimuhā. Tunisia: Dar Al-Gharb Al-Islāmī.

Al-Ghazālī, Abū Hāmid. (2008). AlMustașfā Min 'Ilm Al-Ușūl. Beirut: Dār Al-Gharb Al-Islāmī.

Al-Khādimī, Nūr Al-Dīn bin Mukhtār. (1998). Al-Ijtihād Al-Maqāṣidì. Qatar: Wizārat Al-Awqāf Wa Shuūn AlDīniyyah.

Al-Khādimī, Nūr Al-Dīn bin Mukhtār. (2001). 'Ilm Maqāṣid Al-Sharīah. Riyāḍ: Maktabah Obekan.

Al-Najjār, 'Abd Al-Maj̄̄d. (2008). Maqāșid Al-Sharīah Bi Ab'äd Jadìdah. Beirut: Dār Al-Gharb Al-Islāmī.

Al-Najjār, 'Abd Al-Majīd. (2014). Maqāṣid Al-Sharī'ah Fī Ahkām Al-Usrah Taujīhan Li Ahkām Al-Usrah Al-
Muslimah Fì Al-Gharb. Al-Majallah Al-'Ilmiyyah Li Al-Majlis Al-Aurabā Li Al-Iftà Wa Al-Buhuth, 7: 1-25.

Al-Nasā'ī. (2010). Sunan Al-Nasā'î. Riyāḍ: Dār Al-Haḍārah Li Al-Nashr Wa Al-Tawzī'.

Al-Qaḥtān, Misfir bin 'Alī bin Muhammad. (2010). Manhaj Istinbāt Ahkām Al-Nawāzil Al-Fiqhiyyah AlMu'āsirah. Jeddah: Dār Al-Andalus Al-Khadrā.

Al-Shātịīi, Abū Isḥāq. (2004). AlMuwāäaqāt Fì Ușūl Al-Sharīah. Beirut: Dār Al-Kutub Al-'Ilmiyyah.

Al-Thūfī, Najm Al-Dīn. (1987). Syarh Mukhtashar Ar-Raudhah. Beirut: Muassasah Ar-Risalah.

Al-Zuhailī, Wahbah. (1986). Ușūl Al-Fiqh Al-Islāmī. Damaskus: Dār Al-Fikr.

Auda, J. (2007). Maqasidal-Shari'ah as Philosophy of Islamic Law A System Approach. London: The International Institute of Islamic Thought.

Auda, J. (2008). Maqasidal-Shari'ah a Beginner's. London: The International Institute of Islamic Thought.

Auda, J. (2011). A Maqasidi Approach to Contemporary Application of the Shari'ah. Intellectual Discourse, 19(1), 193-217.

Lihasasanah, A. (2008). Al-Fiqh Al-Maqāșidī 'Inda Al-Imām Al-Shātibì Wa Atharuhu 'Alā Mabāhit Ușul AlTashrī' Al-Islāmī. Kairo: Dār AlSalām.

Salim dan Syahrum. (2012). Metodologi Penelitian Kualitatif. Bandung: Cita pustaka Media.

Wasyith. (2017). Beyond Banking: Revitalisasi Maqāṣid dalam Perbankan Syariah. Economica: Jurnal Ekonomi Islam, 8 (1): 1-25. 